\title{
Challenges Related to the Conversion to Ecological Agriculture of Agricultural Households
}

\section{Cojocaru Olesea*}

Associate Professor, Department of Agronomy and Environment, State Agrarian University of Moldova, Moldova

*Corresponding Author: Cojocaru Olesea, Associate Professor, Department of Agronomy and Environment, State Agrarian University of Moldova, Moldova.
Received: January 29, 2021

Published: March 29, 2021

(c) All rights are reserved by Cojocaru Olesea.
Farmers who apply traditional practices can grow different crops in a dense system, mixed on the same piece of land that changes crop randomly. Several animals can be kept, such as chickens, pigs, cattle, sheep, which scatter manure in their feeding places, thus providing small amounts of plant fertilizers, and the use of mineral fertilizers and pesticides is very low. Usually, for these farmers, the land area is small. Crops may be enough to feed the family, and some may be sold for current income. These farmers already carry out certain practices of organic farming, relying on the farm's own resources, cultivating different crops simultaneously and raising animals. However, there are practices that clearly distinguish these households from organic farms.

The following challenges need to be addressed for conversion:

- Avoid burning secondary production after harvest, because valuable organic material is destroyed and soil organisms are affected;

- Development and implementation of crop rotation, taking into account and meeting the food and health requirements of animals and birds;

- Accumulation of knowledge and practices on the efficient use of the farm's own resources;

- Establishment of a manure collection system for composting;

- Avoiding cutting trees from forest curtains;

- Application of measures to prevent soil erosion;

- $\quad$ Avoiding seed infection, applying preventive measures;

- $\quad$ Avoid crop and storage losses.

Some conversion practices in this system are:

- Application in practice of crop rotation. A combination of annual and perennial crops, including legumes, is required;
- Adequate integration of animals into the agricultural system, as well as planting perennial legume crop strips between annual crops, will improve crop growing conditions and encourage the best possible growth, while providing additional animal feed;

- Improving soil fertility by preparing and applying high quality compost:

- Application of measures to prevent and combat soil erosion, such as cultivating crops across the hill, covering the soil with plant remains, planting forest curtains, etc.

Soils can be degraded due to the lack of anti-erosion organization of agricultural lands, soil conservation measures; crop rotations and perennial weeds, the predominance of weeds on slopes, insufficient amounts of fertilizers incorporated into the soil; land fragmentation and damage to anti-erosion systems, overgrazing, etc. Such soils require more effort and patience to establish good growing conditions for plants. At the same time, ecological practices are an excellent approach to the recovery of these soils. Specific practices may be required to reduce soil degradation and restore its fertility, especially during the conversion period.

Saline soils contain large amounts of water-soluble salts, which inhibit plant germination and growth. These salts could have accumulated due to the use of inadequate irrigation water. Salts should be gradually reduced during the conversion period, ensuring adequate irrigation and improving the structure of the soil with compost, to allow natural drainage of excess salts. In the first stage, salt tolerant crops can be grown.

Flooded land can be improved by creating drainage channels in order to evacuate excess water and ensure good conditions for plant cultivation. In most cases, the growth of organic matter plays 
a key role in improving the quality of degraded soils. Green manures, perennial grasses and compost must be used to restore soil fertility, but also to obtain stable crops on land with degraded soils.

\section{Assets from publication with us}

- Prompt Acknowledgement after receiving the article

- Thorough Double blinded peer review

- Rapid Publication

- Issue of Publication Certificate

- High visibility of your Published work

Website: www.actascientific.com/

Submit Article: www.actascientific.com/submission.php

Email us: editor@actascientific.com

Contact us: +919182824667 